\title{
Note on Sources and Key to Abbreviations and Translations
}

\section{Kant}

Apart from the Critique of Pure Reason, all references to Kant are to Kants Gesammelte Schriften (Ak), ed. Königliche Preussische (later Deutsche) Akademie der Wissenschaften, 29 volumes (Berlin and Leipzig: Walter de Gruyer, 1902). References to the Critique of Pure Reason are to the standard A and B pagination of the first and second editions. Specific works cited in the main body of the text are referred to by means of the abbreviations listed below; those cited only in the notes are given with full title. The translations used are listed as follows and, except in the case of the Critique of Pure Reason, are referred to immediately following the reference to the German text. It should be noted that I have silently modified the English translations throughout. Where there is no reference to an English translation, the translation is my own.

A/B Kritik der reinen Vernunft (Ak 3 and 4 ).

Critique of Pure Reason, trans. Norman Kemp Smith (New York: St. Martin's Press, 1965).

Gr Grundlegung zur Metaphysik der Sitten (Ak 4: 387-463). Grounding for the Metaphysics of Morals, trans. James M. Ellington (Indianapolis: Hackett, 1993). 
KprV Kritik der praktischen Vernunft (Ak 5: I-I63).

Critique of Practical Reason, trans. L. W. Beck (Indianapolis: Bobbs-Merrill, 1956).

MS Die Metaphysik der Sitten (Ak 6: 203-493).

The Metaphysics of Morals, trans. Mary Gregor (Cambridge: Cambridge University Press, 199I).

Rel Die Religion innerhalb der Grenzen der bloßen Vernunft (Ak 6: I-202).

Religion within the Limits of Reason Alone, trans. Theodore M. Greene and Hoyt H. Hudson (New York: Harper and Row, 1960).

SF Der Streit der Fakultäten (Ak 7: I-II6).

The Conflict of the Faculties, trans. Mary Gregor (Lincoln: University of Nebraska Press, 1979).

Auf "Beantwortung der Frage: Was ist Aufklärung?" (Ak 8: 3342).

"An Answer to the Question: "What Is Enlightenment?" Political Writings, ed. Hans Reiss, trans. H. B. Nisbet (Cambridge: Cambridge University Press, 1970), 54-60.

Ton Von einem neuerdings erhobenen vornehmen Ton in der Philosophie (Ak 8: 387-406).

"On a Newly Arisen Superior Tone in Philosophy," Raising the Tone of Philosophy, ed. and trans. Peter Fenves (Baltimore: Johns Hopkins University Press, 1993), 51-72.

DO "Was heißt: sich im Denken orientieren?" (Ak 8: 13I-47). "What Is Orientation in Thinking?" Political Writings, ed. Hans Reiss, trans. H. B. Nisbet (Cambridge: Cambridge University Press, 1970), 237-49.

Freud

All translations of Freud's work will refer to The Standard Edition of the Complete Psychological Works of Sigmund Freud, translated 
from the German under the general editorship of James Strachey in collaboration with Anna Freud, assisted by Alix Strachey and Alan Tyson, 24 volumes (London: The Hogarth Press, 1953-1974). For a critical discussion of the Standard Edition's translations, see Bruno Bettelheim's 1982 article in The New Yorker, "Freud and the Soul," I March 1982, 52-93. All references to this edition will be abbreviated SE followed by volume and page number. German references will be to Freud's Gesammelte Werke, I8 volumes (Frankfurt am Main: Fischer Verlag, 1999). I have silently modified the Standard Edition translations throughout.

\section{Flaubert}

For all letters written after 1875 (and therefore not available in Jean Bruneau's Pléiade edition), I have referred to the Conard second edition of Flaubert's letters and its supplement. For correspondence with Guy de Maupassant, George Sand, and Ivan Turgeniev, I have used the excellent collections published by Flammarion. All translations of Flaubert's correspondence are my own. In the case of Bouvard et Pécuchet where two page numbers are given, the first always refers to the French edition of the text. I have silently modified the Earp and Stonier translation throughout.

BP Bouvard et Pécuchet, ed. Claudine Gothot-Mersch (Paris: Gallimard, 1979). Bouvard and Pécuchet, trans. T. W. Earp and G. W. Stonier (New York: New Directions, 1954).

CB Correspondance, ed. Jean Bruneau, 4 vols. (Paris: Gallimard, I973-I998).

CC Correspondance, 9 vols. (Paris: Conard, 1926-1933).

GM Correspondance Gustave Flaubert-Guy de Maupassant, ed. Yvan Leclerc (Paris: Flammarion, 1993).

GS Correspondance Gustave Flaubert-George Sand, ed. Alphonse Jacobs (Paris: Flammarion, 198I). 
xvi Note on Sources and Key

IT Correspondance Gustave Flaubert-Ivan Tourguéniev, ed. Alexandre Zviguilsky (Paris: Flammarion, 1989).

$S \quad$ Correspondance, Supplement, eds. René Dumesnil, Jean Pommier, and Claude Digeon, 4 vols. (Paris: Conard, I954). 
Je größer das Denkwerk eines Denkers ist, das sich keineswegs mit dem Umfang und der Anzahl seiner Schriften deckt, um so reicher ist das in diesem Denkwerk Ungedachte, d.h. jenes, was erst und allein durch dieses Denkwerk als Noch-nicht-Gedachtes heraufkommt.

—(Martin Heidegger, Der Satz vom Grund)

The greater the work of a thinker-which in no way corresponds to the scope and number of his writings-the richer is that which is unthought in this work, namely, that which for the first time and through this work rises to the surface as having not-yet-been-thought.

-(Martin Heidegger, The Principle of Reason) 
This page intentionally left blank 